\title{
A Test to Measure Dairy farmers' Knowledge towards Climate Variability
}

\author{
J. Parameswaranaik ${ }^{*}$, R. Senthil Kumar and A. P. Verma \\ Dairy Extension Division, ICAR- National Dairy Research Institute, Karnal-132001, India \\ *Corresponding author
}

\section{A B S T R A C T}

Keywords

Climate variability,

Knowledge, Northern

dry of Karnataka,

Point-bi-Serial

Correlation.

\section{Article Info}

Accepted:

12 September 2017

Available Online:

10 November 2017
A standardized test was developed to measure the extent of knowledge of dairy farmers towards climate variability. Initially 36 items list was prepared which were related to general aspects of climate variability and its effect on animals were selected with discussion of experts from the ICAR-National Dairy Research Institute, Karnal. Further it was processed by pretesting and item analysis method with using difficulty index and discrimination index, as based on the result obtained after calculation some of the items excluded for next step and those items which satisfied the given standard criteria such items are again subjected to point bi serial correlation and eventually items which shows the significance value were remained for the final test so in total 18 items were selected for the final Knowledge test.

\section{Introduction}

The climate variability is increasingly becoming an important consideration of our lives. Climate variability refers to the way climate fluctuates yearly above or below a long-term average value. The warming trend in India over the past century was estimated to be $0.60{ }^{\circ} \mathrm{C}$. The IPCC (2007) predicted that by the year 2100 increase in global average surface temperature may be between 1.8 and $4.0{ }^{\circ} \mathrm{C}$, with global average temperature increases by $1.5-2.5^{\circ} \mathrm{C}$. Approximately 20-30 percent of plant and animal species are expected to be at risk of extinction (FAO, 2007). Livestock sector plays a prominent role in the economic progress of the country as it provides employment to people in principle or subsidiary status. In recent times, climate variability has been considered as one of the most serious long-term challenge faced by farmers. Till date very few studies have been done on the development of knowledge test towards climate variability especially about livestock rearers, as of now no any standardized knowledge test in India to measure the livestock rearers' knowledge towards climate variability. The present study is a humble attempt in that direction.

\section{Materials and Methods}

The study was conducted in Northern dry zone area which was purposively selected because of this zone is most frequently exposed to climate variability. Nearly 70 percent of its area falls under dry land farming. Raichur and Bellary Districts are 
coming under this dry zone were selected purposively for the study, as these districts holds largest livestock population in northern dry zone of Karnataka. From each districts two taluks have been selected randomly eventually from each taluks two villages selected randomly. From each selected village, 15 dairy farmers were selected randomly. Thus, total 120 dairy farmers spread over in eight villages of Manvi, Raichur, Huvinahadagli and Bellary taluks constituted the sample for the study.

The following steps were followed in development of knowledge test.

\section{Collection of items}

The content of knowledge test was composed of various questions called items. A comprehensive list of items on climate variability was prepared by consulting relevant literature and experts of ICAR National Dairy Research Institute, Karnal.

Also, every effort was made to see that the sentences were simple, easily understood and each had only one idea. Equal numbers of positive and negative sentences were randomly mixed. Selection of the items was done on the basis of following criteria:

It should promote thinking

It should have a certain difficulty

It should differentiate the well informed from the less knowledgeable

A total of 38 items representing climate variability were selected to form the initial test battery to carry out items analysis for the development of standardized knowledge test. The items were of objective type and dichotomous. This was done to facilitate scoring more easily and objectively.

\section{Pre testing and item analysis}

The preliminary knowledge test consisting of 38 items was administered to 36 dairy farmers. A score of 1 was accorded to correct answers and 0 to incorrect answer. Then the total score of each, respondent was calculated by summing of their score for all the items. These responses were subjected to difficulty index, discrimination index and point-bi-serial correlation.

\section{Difficulty index}

The difficulty index of an item or question varied from individual to individual. Difficulty index of an item refers to relative difficulty to the respondents to answer correctly to the item or question. The index was calculated for each of the 48 item by dividing total correct responses for a particular item by total number of respondents as given in the formula here 0

$D I=\frac{N C}{n}$

Where,

DI $=$ Difficulty index

$\mathrm{NC}=$ Number of respondents answering correctly

$\mathrm{n}=$ Total number of respondents

On the basis of above criteria, the below mentioned items with extreme item difficulty percentages were discarded from the test. The cutting points arbitrarily chosen were 40 and 10 for high and low scores respectively.

The remaining 36 items with moderate difficulty percentages were however, retained in the test and were subjected to item discrimination test. 


\section{Discrimination index}

If a statement is answered correctly by every respondents or none in the sample, then it has no discrimination power, whereas, if a statement is answered by some respondents correctly and not by others, such statement has greater power to discriminate the more knowledgeable respondents from the less one.

Hence, only those statements having higher degree of discrimination with respect to varying knowledge level of the respondents were considered for final selection.

The discrimination indices of all the 36 raw items were worked out by the following procedure.

At the first, the respondents were arranged and listed in descending order on the basis of their performance in the whole test, out of this list. Top 25 percent and bottom 25 percent of the respondents were considered as high and low groups respectively. Then for each item or question, the number of respondents in the high and low groups who answered it correctly was counted. Finally, the discrimination index (di) was calculated for each item by using following formula.

$d i=\frac{N H+N L}{n}$

Where,

di $=$ Discrimination index

$\mathrm{NH}=$ Number of non-sample respondents in top 25 percent or high groups who answered correctly

$\mathrm{NL}=$ Number of non-sample respondents in bottom 25 percent low groups.

$\mathrm{n}=$ Total number of non-respondents

\section{Point-bi-serial correlation}

Point-bi-serial correlation was worked out to check the internal consistency of items i.e., the relationship of the total score to a dichotomized answer to any given item. In other words, the validity power of item was computed by the correlation of the individual item of the whole test. The point-bi-serial correlation for each of the item of preliminary knowledge test was calculated by using the formula suggested by Garrett (1966).

rpbis $=\frac{\mathrm{Mp}-\mathrm{Mq}}{\mathrm{SD} * \mathbf{p q}}$

rpbis $=$ Point-bi-serial correlation

$\mathrm{Mp}=$ Mean of the total score of the non sample respondents, who Answered particular item correctly

$\mathrm{Mq}=$ Mean of the total score of the nonsample respondents, who, Answered the same item incorrectly

$\mathrm{SD}=$ Standard deviation of the entire sample

$\mathrm{p}=$ Proportion of the respondents who answered correctly to the same item.

$\mathrm{q}=$ Proportion of the respondents who answered incorrectly to the same item.

The calculated point-bi-serial correlation was statistically tested with the help of the table for $(\mathrm{n}-2)$ degree of freedom.

\section{Final selection of items}

Those, items, which met al.,1 the following conditions, were finally selected for the knowledge test based on the following criteria.

Difficult index (Di) between 0.25 to 0.75 
Discrimination index (di) above 0.20

Point-bi-serial correlation coefficient at 5 percent level of significance

\section{Results and Discussion}

Total of 18 items were selected for the final knowledge test a list of final selected items was selected and each practice was put in the question form to the respondents to obtain the response.

The answer elicited from the livestock rearers were quantified by assigning one score to correct answer and zero to wrong one, the score of all the individual items which were answered correctly by respondents were summed up to get the knowledge score of the respondents.

The maximum score a respondent could obtain is 18 and minimum score is 0 with respect to knowledge items.

Some of the items were rejected after the calculation of difficulty index and discrimination index, these statement were falling in difficulty index more than 0.75 and discrimination index less than 0.20 . So these items were excluded for the further analysis those items are as follows.

\section{Rejected items after analysis}

1. Do you agree with statement as climate change and global warming is same thing?

a) Yes b) No c) No idea

2. Which of one following gas is more responsible for climate variability and change?

a) Carbon $\mathrm{Di}$ oxide $\left(\mathrm{CO}_{2}\right)$ b) Ozone c) Methane d) Nitrous Oxide $\left(\mathrm{N}_{2} \mathrm{O}\right)$
3. Which of the following are mainly responsible for emitting greenhouse gases?

a) Trees, herbs, shrubs b) Bovine and ovine

c) Insects, fishes, etc. d) None of the above

4. Which of one following gas i.e. responsible for climate change emitted due to application of chemical fertilizer in Field?

a) Carbon Di Oxide $\left(\mathrm{CO}_{2}\right)$ b) Ozone c) Methane d) Nitrous Oxide $\left(\mathrm{N}_{2} \mathrm{O}\right)$

5. Which of the following is the most likely impact in semi-arid ecosystem of India due to climatic change and global warming?

a) Increased desertification b) Decreased desertification c) No impact d) No idea

6. Have you noticed that there is emergence and re-emergence of diseases due to climate variability and change?
a) Yes b) No c) Don't know

7. Effect of heat stress on reproduction of livestock
a) Decreased fetal growth and calf size
b) Increased fetal growth and calf size
c) No effect on reproduction
d) No idea

8. What is the indicator of heat stress in a dairy animal?

a) Normal behavior b) Increased salivation

c) Decreased water intake d) No idea

9. Impact of unfavorable climate variability and change on death rate of dairy animals will be

a) Increased b) decreased c) Constant d) Don't know 
Table.1 The Point-Bi serial (rpb) values of the 18 items retained in the knowledge test

\begin{tabular}{|c|c|c|}
\hline $\begin{array}{l}\text { Sl. } \\
\text { No }\end{array}$ & Statements & $\begin{array}{c}\text { rpb } \\
\text { value }\end{array}$ \\
\hline 1 & Have you heard about climate variability? & $\begin{array}{c}0.24 \\
\mathrm{P}<0.05\end{array}$ \\
\hline 2 & What do you mean by climate variability? & $\begin{array}{c}0.20 \\
\mathrm{P}<0.1\end{array}$ \\
\hline 3 & Which of the following is human induced cause of climate variability? & $\begin{array}{c}0.25 \\
\mathrm{P}<0.05\end{array}$ \\
\hline 4 & $\begin{array}{l}\text { Do you know that practices like Destruction, burning of crop/fodder residues } \\
\text { in field is also contributing towards climate variability? }\end{array}$ & $\begin{array}{c}0.42 \\
\mathrm{P}<0.001\end{array}$ \\
\hline 5 & Effect of climate variability on distribution of rainfall over the years is & $\begin{array}{r}0.19 \\
\mathrm{P}<0.1\end{array}$ \\
\hline 6 & Compared to earlier decades, temperature as an effect of climate variability is & $\begin{array}{c}0.18 \\
\mathrm{P}<0.1\end{array}$ \\
\hline 7 & $\begin{array}{l}\text { Do you know the impending climate variability may increase the occurrence of } \\
\text { vector born diseases on dairy animals? }\end{array}$ & $\begin{array}{c}0.21 \\
\mathrm{P}<0.1\end{array}$ \\
\hline 8 & $\begin{array}{l}\text { In long run due to climate variability in case of temperature related illness on } \\
\text { dairy animals will be }\end{array}$ & $\begin{array}{c}0.28 \\
\mathrm{P}<0.05\end{array}$ \\
\hline 9 & Which types of animals are more sensitive to climate variability? & $\begin{array}{c}0.20 \\
\mathrm{P}<0.1\end{array}$ \\
\hline 10 & $\begin{array}{l}\text { Indigenous breeds are preferred for rearing against climate variability because } \\
\text { of }\end{array}$ & $\begin{array}{c}0.32 \\
\mathrm{P}<0.05\end{array}$ \\
\hline 11 & $\begin{array}{l}\text { Do you know that climate stress has negative impact on reproduction } \\
\text { performance of dairy animals? }\end{array}$ & $\begin{array}{c}0.25 \\
\mathrm{P}<0.05\end{array}$ \\
\hline 12 & $\begin{array}{l}\text { Effect of climate change will increases the overgrazing in community grazing } \\
\text { land }\end{array}$ & $\begin{array}{c}0.19 \\
\mathrm{P}<0.1\end{array}$ \\
\hline 13 & Which of the following is resistant against in adverse climate effect? & $\begin{array}{c}0.25 \\
\mathrm{P}<0.05\end{array}$ \\
\hline 14 & What is the adverse effect of Heat stress on dairy animals during feed intake? & $\begin{array}{c}0.20 \\
\mathrm{P}<0.1\end{array}$ \\
\hline 15 & $\begin{array}{l}\text { Do you agree with Heat stress on the dairy animals will affect the milk } \\
\text { production? }\end{array}$ & $\begin{array}{c}0.29 \\
\mathrm{P}<0.01\end{array}$ \\
\hline 16 & $\begin{array}{l}\text { Do you agree that due to climatic variability there is shortage of fodder will } \\
\text { occur in long run? }\end{array}$ & $\begin{array}{c}0.17 \\
\mathrm{P}<0.01\end{array}$ \\
\hline 17 & $\begin{array}{l}\text { Effect of climate variability on availability of ponds and other natural water } \\
\text { resources for livestock? }\end{array}$ & $\begin{array}{c}0.27 \\
\mathrm{P}<0.05\end{array}$ \\
\hline 18 & Due to the effect of climate variability on grazing and pasture land area & $\begin{array}{c}0.32 \\
\mathrm{P}<0.05\end{array}$ \\
\hline
\end{tabular}




\section{Items retained for final knowledge test with options}

1) Have you heard about climate variability?

a) Yes b) No

2) What do you mean by climate variability?

a) No change in temperature

b) Temperature fluctuations, long dry spells and increased rate of heat and cold waves, Unpredictable rainfall etc

c) No change rainfall

d) None of the above

3) Which of the following is human induced cause of climate variability?

a) Solar radiation b) Ocean current

c) Deforestation d) Don't know

4) Do you know that practices like Destruction, burning of crop/fodder residues in field is also contributing towards climate variability?

a) Yes b) No c) No Idea

5). Effect of unfavorable climate variability on distribution of rainfall over the years is

(a) Erratic (b) Even (c) No change (d) Don't know

6). As compared to earlier decades, temperature as an effect of climate variability is

(a) Increased (b) Decreased (c) No change (d) Don't know

7) Do you know the impending climate variability may increase the occurrence of vector born diseases on dairy animals?

a) Yes b) No c) Don't know

8) In long run due to climate variability in case of temperature related illness on dairy animals will be

a) Reduces b) Increase c) Remain same d) Don't know
9) Which type of animals is more sensitive to climate variability?

a) Cross breed animals b) Indigenous breeds

c) Both a and b d) No effect on animals

10). Indigenous breeds are preferred for rearing against climate variability because of a) Susceptible to poor nutrition b)Tolerance to heat stress

c) Susceptible to diseases d) None of the above

11) Do you know that climate stress has negative impact on reproduction performance of dairy animals?

a) Yes b) No c) Don't know

12) Effect of climate change will increases the overgrazing in community grazing land

a) Yes b) No c) Don't know

13) Which of the following option is resistant against to disease due to adverse climate effect?

a) Cross breed animals b) Indigenous breeds

c) Both $a$ and $b$ d) No effect on animals

14) What is the adverse effect of Heat stress on dairy animals during feed intake?

a) Reduces b) Increase c) Remain same d) Don't know

15) Do you agree with Heat stress on the dairy animals will affect the milk production?

a) Yes b) No c) Don't know

16) Do you agree that due to climatic variability there is shortage of fodder will occur in long run?

a) Yes b) No c) Don't know

17) Effect of climate variability on availability of ponds and other natural water resources for livestock?

a) Reduces b) Increase c) Remain same d) Don't know 
18) Due to the effect of climate variability on grazing and pasture land area

a) Decrease b) Increase c) Remain same d) Don't know

The findings of the study revealed that all the questions included in the knowledge test in order to find out the knowledge of the participants, without standardizing the knowledge test does not give the statistically correct knowledge score of the participants.

It implies that the knowledge test must be standardized as discussed in this study and which can be used to further in measurement of extent of knowledge of livestock rearers towards climate variability for accuracy of results.

Knowledge test would be great impetus to study the farmers' Knowledge level irrespective of the climate regions and eventually useful for the Natural resource assessment, Environment Impact study at field level.

\section{References}

Garrett, E. and Woodworth, R.S. (1969). Statistics in psychology and education. Bombay: Vakils Feffer and Simons private Limited. Pp: 329

IPCC (2007). Climate Change 2007: Synthesis Report: Contribution of Working Groups I, II and III to the Fourth Assessment Report of the Intergovernmental Panel on Climate Change, Core Writing Team, Pachauri $\mathrm{R} \mathrm{K}$ and Reisinger A, IPCC, Geneva, 2008, Pp: 45.

Sarkar, S. and Padaria, R.N. (2010). Farmers' awareness and risk perception about climate change in coastal ecosystem of West Bengal. Indian Research Journal of Extension Education, 10(2):32-38.

\section{How to cite this article:}

Parameswaranaik, J., R. Senthil Kumar and Verma, A.P. 2017. A Test to Measure Dairy farmers' Knowledge towards Climate Variability. Int.J.Curr.Microbiol.App.Sci. 6(11): 12541260. doi: https://doi.org/10.20546/ijcmas.2017.611.149 